University of Nebraska - Lincoln

DigitalCommons@University of Nebraska - Lincoln

September 2007

\title{
African-American Committee Chairs in U.S. State Legislatures
}

\author{
Byron D. Orey \\ borey2@unl.edu \\ L. Marvin Overby \\ University of Missouri \\ Christopher W. Larimer \\ University of Northern lowa
}

Follow this and additional works at: https://digitalcommons.unl.edu/poliscifacpub

Part of the Political Science Commons

Orey, Byron D.; Overby, L. Marvin; and Larimer, Christopher W., "African-American Committee Chairs in U.S. State Legislatures" (2007). Faculty Publications: Political Science. 22.

https://digitalcommons.unl.edu/poliscifacpub/22

This Article is brought to you for free and open access by the Political Science, Department of at DigitalCommons@University of Nebraska - Lincoln. It has been accepted for inclusion in Faculty Publications: Political Science by an authorized administrator of DigitalCommons@University of Nebraska - Lincoln. 


\title{
African-American Committee Chairs in U.S. State Legislatures*
}

\author{
Byron D’Andra Orey, University of Nebraska, Lincoln
}

L. Marvin Overby, University of Missouri

Christopher W. Larimer, University of Northern Iowa

Objective. In this article, we explore whether African-American state legislators have been able to translate election to office into positions of power, particularly as committee chairs. Methods. We cull data from all state legislative chambers that contained a black legislator during two time periods, 1989 and 1999. In doing so, we compare the observed numbers of African-American chairs with their expected numbers. We also examine each state's percentage of black chairs using multiple regression to determine what factors-political, partisan, institutional, culturalinfluence the selection of black committee chairs. Results. Overall, our descriptive analysis reveals that blacks are underrepresented as chairs. They are not, however, significantly underrepresented as chairs of the most important committees and they are generally overrepresented as chairs of committees with jurisdiction over social services. Our multivariate analyses show that the prevalence of black chairs is driven primarily by factors related to partisan control of legislative chambers and size of the black legislative delegation, and that these dynamics have changed over time. Conclusion. Although the increase in African-American state legislators has led to an increase in substantive leadership roles, these positions have been limited almost entirely to chambers where the black caucus is a critical element of a Democratic majority.

As the United States enters the 21st century, race continues to be the distinctively "American dilemma" identified by Myrdal (1944) over 60 years ago. Although African Americans have made substantial progress in many areas, numerous economic, social, and political problems persist. In the political arena, African Americans have made considerable advances since the passage of the Voting Rights Act in the mid1960s. Although election rates still lag behind their percentage of the

\footnotetext{
*Direct correspondence, including data requests for replication purposes, to Professor Byron D'Andra Orey, Department of Political Science, 511 Oldfather Hall, University of Nebraska, Lincoln, NE 68588-0328〈borey2@unlnotes.unl.edu〉. This project was partially funded by a Senning Fellowship from the University of Nebraska. We express our appreciation to Bob Darcy and Robert Mickey for their guidance on a much earlier version of this article. We also express our thanks to Joel Wiegert and Mitch Herrian for their datacollection efforts. Finally, the first author would like to thank the late Dan Orey, Jr. for his inspiration and guidance.
} 
population, ${ }^{1}$ the past several decades have seen minority enfranchisement translated into the election of significant numbers of minority representatives at the local, state, and national levels. In this article, we examine an underexplored aspect of minority representation, the extent to which African-American representatives have attained significant positions of influence in policy-making institutions, specifically the rates at which they serve as committee chairs in state legislatures. With key provisions of the Voting Rights Act renewed in 2006, it seems an appropriate time to assess the degree to which African Americans have been able to translate their presence in state legislatures into an ability to have a significant impact on policy. Since committees play such an important role in legislative decision making, an examination of the prevalence — or paucity—of black committee chairs will allow us important insights into the extent to which African Americans have gained substantive, as well as merely descriptive, representation. Our analysis will also illuminate recent changes in the dynamics of black political empowerment in the states and allow us to explore the conditions that promote greater African-American political influence in state legislatures.

\section{Background}

In the 1982 amendments to the Voting Rights Act (VRA), Congress significantly expanded state responsibility to take proactive steps to maximize minority representation; and in the 1986 case of Thornburg $v$. Gingles, the Supreme Court introduced three explicit standards for determining vote dilution. ${ }^{2}$ These standards played a vital role in increasing the number of minority elected officials nationwide. The full impact of the new federal guidelines was felt in the redistricting required following the 1990 Census. Prior to this redistricting cycle, African-American voters constituted a majority in only 15 congressional districts nationwide. Following the redistricting cycle, the number of such districts nearly doubled nationwide, up to 27. At the state-legislative level, the numbers are even more impressive. Nationwide, the amended VRA resulted in the creation of 57 new state senate districts and 109 new state house districts in which there were African-American majorities (APSA, 1993). A good percentage of this increase in minority representation has come in southern states, where a majority of African Americans reside. Although historically the states of the

\footnotetext{
${ }^{1}$ For instance, while African Americans constitute roughly 12 percent of the U.S. population, they account for only 8 percent of the members of Congress (Davidson and Oleszek, 2006:121).

${ }^{2}$ Under the so-called Gingles criteria, the Court established a three-part test to determine violations of the Voting Rights Act: "Is a minority group sufficiently large and compact to form a majority in a district? Is it politically cohesive? Is there evidence of racially polarized voting against it?" (Butler and Cain, 1992:36).
} 
former Confederacy went to extraordinary lengths to disfranchise minority voters, dilute the impact of those who did vote, and limit - if not eliminate-minority office holders, the Voting Rights Act and its amendments have resulted in a "quiet revolution" in the region (Davidson and Grofman, 1994) that has resulted in the election of significant numbers of minority lawmakers in every southern state. Here we seek to assess how far this "quiet revolution" has worked its way up the legislative ladder, examining the extent to which minority electoral success has been translated into effective legislative power, in the South and elsewhere.

Given the historic increase in the number of black elected officials, questions abound regarding their effectiveness in substantively representing African-American interests. Central to this debate is whether electing black officials results in an increase in policy outputs favored by blacks. Pitkin's seminal work on representation (1967) distinguishes three types of representation. She argues that representation can be descriptive in that legislators and those they represent share similar physical traits, such as ethnicity, race, or gender; symbolic in that legislators have the confidence of those they represent, even if they accomplish little in terms of policy; or substantive in that legislators deliver policy outcomes that are favored by their constituents. Following the passage of the Voting Rights Act of 1965 and its amendments in 1982, African Americans clearly experienced an increase in descriptive representation, but it is less clear whether this descriptive representation has been translated into substantive representation. Indeed, much recent scholarship has questioned this point explicitly, enumerating the political tradeoffs that often accompany the creation of majority-minority districts. Scholars such as Brace, Grofman, and Handley (1987), Bullock (1995), Hill (1995), Cameron, Epstein, and O’Halloran (1996), Lublin (1997), Lublin and Voss (2000), and Shotts (2001) have all argued that racial redistricting tends to "waste" at least some Democratic voters and can lead to significant Republican electoral gains. Swain (1993) and Overby and Cosgrove (1996) show a further "waste" of minority constituents, leading surviving white Democratic legislators to be less sympathetic to minority policy concerns.

However, relatively few studies have empirically examined the behavior of African-American legislators and the positions they hold in the legislative process (but see Bratton and Haynie, 1999; Legette, 2000; Orey, 2000; Grose, 2005; Orey and Smooth, forthcoming). It is possible that even accounting for the tradeoffs enumerated by critics, the election of more black legislators increases substantive representation of black interests by increasing the number of African Americas who hold positions of substantial legislative authority. This study will give us some purchase on that question, as it relates to committee leadership.

Since the passage of the VRA, research in the area has evolved over "four generations." In their study of the impact of voting rights from 1965 to 1990, Davidson and Grofman (1994) indicate that "first-generation" 
research questions focused on minority enfranchisement matters from the 1960s; "second-generation" questions dealt with subsequent vote dilution efforts and the election of minority officeholders. "Third-generation" research questions have examined the extent to which minority officials are able to "become an integral part of the political process: operating inside the system without being discriminated against, forming multiethnic coalitions, and working out resolutions to problems with fellow officials, in short finding acceptance as active, influential players in the mainstream political game" (Davidson and Grofman, 1994:14). "Fourth-generation" research examines whether black legislators are able to introduce and pass legislation on behalf of their constituents. Unfortunately, most of the research examining these issues has focused on first-, second-, and fourth-generation questions, leaving something of a void in our understanding of critical thirdgeneration questions. In this article, our focus on African-American committee chairs addresses this imbalance in the literature, examining a critical and largely overlooked topic from the "third generation."

We focus on state legislative committee chairs for several reasons. First, committee chairs have considerable power in most legislative chambers, including the states. As Jewell and Patterson (1986:154) conclude, "committee procedures and practices in many states give the chair $[s]$... a great deal of leeway in running the committees" (see also Lacy, 1967; Keefe and Ogul, 2001). ${ }^{3}$ Chairs often use this latitude to enhance their influence in terms of setting the legislative agenda, prioritizing legislation, influencing what bills make it to the floor (and in what form), affecting fiscal priorities, and the like. ${ }^{4}$

Second, unlike in the Congress, where chairs are chosen through a (more or less rigid) seniority system (see, e.g., Gerber, 1996), in the states there is more diversity in the selection process. Party leaders make many such appointments, although some states use chamberwide elections, caucus selections, or committees-on-committees to choose committee chairs; only four state legislative chambers rely solely on seniority. Given the relative recentness of the election of large numbers of minorities to the nation's legislative bodies and the torpid pace at which actuarial forces can affect seniority, we

${ }^{3}$ Hall's (1996) observations about selective participation among members of Congress undoubtedly pertain to state legislators as well. One reason why state legislative chairs are powerful is that they focus their energies on committee work and opt to participate when rank-and-file members are distracted by other tasks.

${ }^{4}$ The Supreme Court has certainly recognized this point in recent decisions regarding assessment of minority representation. In her opinion in the 2003 case of Georgia v. Ashcroft, Justice Sandra Day O'Connor wrote: “one other method of assessing the minority group's opportunity to participate in the political process is to examine the comparative position of legislative leadership, influence, and power for representatives of the benchmark majorityminority districts. Indeed, in a representative democracy, the very purpose of voting is to delegate to chosen representatives the power to make and pass laws. The ability to exert more control over that process is at the core of exercising political power. A lawmaker with more legislative influence has more potential to set the agenda, to participate in closed-door meetings, to negotiate from a stronger position, and to shake hands on a deal." 
would expect to see evidence of meaningful percentages of minority chairs in the state houses before they appear on Capitol Hill.

Third, an analogous study by Darcy (1996) regarding female committee chairs in state legislatures provides a readily adaptable template for our current project. Darcy's techniques and use of basic probability statistics have proven useful in assessing the institutional power of female legislators, and lend themselves to similar assessments in regard to African-American legislators. In addition, we supplement his statistical techniques with multivariate analysis to explore with greater rigor the conditions that facilitate the ability of minority legislators to rise to the level of committee leadership.

In the following sections, we outline our expectations more fully, discuss the data and methods we employ, summarize our findings, and consider what these findings imply about the status of black political empowerment and the utility of majority-minority legislative districting.

\section{Expectations}

To guide our exploration, we will discuss a number of expectations, which in turn suggest a series of testable propositions related to minority political empowerment and legislative representation.

Darcy (1996) found that female legislators were not proportionately underrepresented as committee chairs; however, historically, the level of prejudice in the United States has been much stronger toward citizens of African descent than it has been toward women. Although the political manifestations of that prejudice have abated since the 1960 s, we suspect that African-American legislators continue to be underrepresented in positions of legislative leadership. For example, Haynie (2002) finds that even after obtaining office, African-American legislators are at a disadvantage relative to nonblack legislators. His findings reveal that African-American legislators tend to be viewed as less effective by their fellow colleagues in the legislature than their nonblack counterparts, even after controlling for positions of power (Haynie, 2002:304). This leads us to suspect that, unlike the situation with female legislators, relative to their numbers in the parent chamber, African-American state legislators will be underrepresented as committee chairs.

Our second expectation concerns majority-minority districting schemes. Critics of such procedures have argued that overtly packed, majorityminority districts are counterproductive, in part because they can lead to increased animosity among otherwise sympathetic white lawmakers, a point made strongly by Guinier (1994). There is reason to suspect this is especially true among white Democrats, who in many states watched the Republican Party join forces with black Democrats to advocate for the creation of majority-minority districts that put many of them in electoral 
danger. ${ }^{5}$ From the front lines, an African-American state legislator in Mississippi noted that following the state's redistricting in the early 1990s:

there has been an effort to send a message to us, and to black Mississippians, that no matter what your numbers in the legislature, we're going to still control things.... We no longer have the clout that we once had with those progressive whites, because they feel that they were betrayed [in the redistricting process], and in general they were. (Rep. Barney Schoby, National Public Radio, 1993)

If elite-level bias does accompany the creation of majority-minority districting in such a way as to make it more difficult for African-American legislators to exercise legislative power through committee leadership, it should be most apparent in the South, the region with the most tortured history of racial tension and the most experience with racially-motivated redistricting. Therefore, we expect that compared to their numbers in the parent chamber, African Americans will be more underrepresented among the ranks of committee chairs in southern state legislatures than in nonsouthern legislatures.

Of course, it is a matter of faith among legislative scholars that not all committees are created equal and that in the legislative pecking order the most important are those that deal with monetary matters (such as taxation policy and spending decisions) and those that control the access of legislation to the floor (i.e., rules committees) (Fenno, 1973; Mayhew, 1974; Smith and Deering, 1990). Even if African-American representatives have been able to rise to the rank of committee chairs, if they are underrepresented among the leaders of these powerful committees, their influence in state legislatures may be artificially attenuated in relation to their numbers. There is at least some reason to believe this is the case. In his study of the Mississippi Legislature, Orey (2000) quotes a prominent black legislator arguing that members of the assembly's African-American caucus were systematically excluded from the chamber's "money committees." 6 Based on such observations, we expect that relative to their numbers in the parent chamber, African-American representatives will be underrepresented as chairs of important fiscal, rules, and business committees in U.S. state legislatures.

Relatedly, and as the flip side of the previous hypothesis, we speculate that African-American legislators may be better represented among the leadership ranks of certain other types of committees. Bratton and Haynie (1999; see also Haynie, 2001; Orey and Smooth, forthcoming), for instance, have

${ }^{5}$ At the congressional level, Bullock (1995) notes that "all districts held by Democrats in 1991 in which redistricting reduced the black percentage by more than 10 points have now fallen to the Republicans" (see, however, Engstrom, 2006).

${ }^{6}$ See also Haynie (2002). Similarly, Darcy (1996) found that female representatives were underrepresented on legislative rules committees, but not on fiscal or business-related committees. 
found that African-American legislators are more likely than their white counterparts to introduce legislation that addresses education, health, and social welfare matters. Since such issue areas have traditionally been of interest to African-American legislators, it seems reasonable to expect that compared to their overall numbers, African-American legislators will be better represented as chairs of committees whose jurisdictions include education, health, and social welfare policy than as chairs of other types of committees.

Fifth, following earlier work on female legislators (especially Darcy, Welch, and Clark, 1994; Darcy, 1996), we suspect that some methods of chair selection may be more favorable to African Americans than are others. Generally speaking, rules that permit the selection of committee chairs by legislative leaders may provide for greater ability to "balance tickets" and to fix accountability than rules that permit the election of chairs (Darcy, 1996), therefore promoting the appointment of minority committee chairs. Haynie's (2002) finding that legislators tend to view their African-American colleagues as less effective than their nonblack colleagues further suggests that chair appointment methods that allow for the selection of committee chairs, as opposed to election, may be advantageous to African-American legislators. Therefore, we hypothesize that African-American committee chairs will be more prevalent in legislatures that select rather than elect such posts.

Sixth, term-limited legislatures may well decrease opportunities for black legislators to achieve higher levels of leadership. Gerber's (1996) study of the U.S. Congress reveals that African Americans are less likely to exit office when compared to other members of Congress. Based on these findings, Gerber posits that "African Americans representatives would be hit especially hard by legislative term limits" (1996:843; see also Carey, Niemi, and Powell, 2000; on the effect of term limits on the value of committee chairs generally, see Carey et al., 2006). We suspect, therefore, that AfricanAmerican legislators will be less likely to hold committee chairs in legislative chambers where term limits have taken effect.

Finally, African Americans-at both the elite and mass levels-are much more likely to identify with the Democratic Party than with the GOP. Indeed, the size of this partisan disparity is the principal factor that forces our analysis to diverge somewhat from Darcy's previous work on female legislators. Although there is a noticeable gender gap between the parties at both mass and elite levels in the United States, it is quite small in comparison to the racial gap. At the mass level, the partisan gender gap usually falls within the range of high single or low double digits, in terms of both party identification and vote choice. At the elite level, this is matched by a larger number of Democratic female elected officials. Of the 83 women serving in the 109th Congress (69 in the House, 14 in the Senate), roughly two-thirds are Democrats ( 46 members of Congress, nine senators). Similarly, over the past 25 years or so, roughly 60 percent of female state 
legislators have been Democrats (National Conference of State Legislatures, 2005). In contrast, the racial gap between the parties is much larger. At the mass level, it is common to see an 80-point gap between the black vote for Democratic and Republican candidates. This translates to a much larger black presence among Democratic elected officials than among Republicans. In the 109th Congress, of the 43 African-American members of the House (42) and Senate (one), all are Democrats. Figures at the state-legislative level are almost as lopsided. In 1989, there were only two black Republican state legislators nationwide; by 1999 , that number had grown, but only to three. ${ }^{7}$ This partisan disparity has both substantive and methodological implications for our analysis. Since they are such an important, loyal core constituency for the Democratic Party, we suspect there is probably an interactive effect at work when it comes to the appointment of committee chairs, with black legislators more likely to be rewarded with chair positions as their importance to the maintenance of a Democratic majority grows. We summarize this expectation by hypothesizing that African-American committee chairs will be especially prevalent in chambers that have both Democratic majorities and sizable contingents of black legislators. Conversely, since the numbers of black Republican state legislators are so diminishingly small, in our multivariate analysis we include interactive terms for each other independent variable and Democratic control of the legislative chamber, which will allow us to focus more clearly on the factors that are important for the emergence of black committee chairs in those chambers where such an outcome is a real political possibility (i.e., in chambers with Democratic majorities).

In the following sections, after summarizing our data and methods, we subject these expectations to empirical scrutiny, first by describing the distribution of African-American committee chairs across the state legislatures, and then in a more sophisticated fashion by examining the factors that appear to contribute to their selection and how such factors change over time.

\section{Data and Methods}

We rely heavily on data on state legislative committee chairs collected by the Council of State Governments, the 1993 Black Elected Officials directory (Joint Center for Political and Economic Studies, 1993) and the 1999-2000 Directory of African American Legislators published by the National Black Caucus of State Legislators.

\footnotetext{
${ }^{7}$ None of these three black Republican state legislators served as a committee chair in 1999-2000. It is worth noting that unlike in the U.S. Congress, where committee chairs are always members of the majority party, state legislative chambers do sometimes allow members of the minority party to chair committees. Although this is an unusual practice, in 19992000, five black Democrats chaired committees in GOP-controlled legislative chambers (one in the South Carolina House, three in the Virginia House of Delegates, and one in the Texas Senate).
} 
Following Darcy (1996), our first task is a descriptive one, comparing the actual number of African Americans selected to chair state legislative committees with the number that would be expected given their prevalence in the parent chamber. In our case, we examine "snapshots" from two periods of recent history: the late 1980s, immediately before the most extensive round of racial redistricting to date brought large numbers of new AfricanAmerican officeholders into state legislatures, and the late 1990s, the end of a decade of such redistricting. Before doing so, however, it is necessary to understand that other factors also affect chairs' selection and to control for these influences. In his study of female legislative chairs, Darcy (1996) concluded that when evaluating how well actual numbers of female chairs comport with predictions based on the number of women legislators in a legislature, it is necessary to account for legislative chamber, political party, and seniority. ${ }^{8}$ Following Darcy (1996), we account for the relevant "pools" from which African-American committee chairs could be drawn and evaluate the number of chairs actually selected from each relevant "pool" with the number of chairs we would expect to be selected from it purely on the basis of its size. Within states, we compute the expected numbers of AfricanAmerican chairs by calculating the proportion of committee chairs selected from each pool, multiplying this by the percentage of African-American legislators in the pool, and then sum across all pools.

Table 1 summarizes relevant information concerning the relative frequency of committee chairs among important legislative subgroups across the states for the latter of the time periods we consider here (i.e., 19992000).

Moving beyond the example provided by Darcy, we will also attempt to account for the variations we see in the numbers of black committee chairs across state legislative chambers, employing multivariate equations and ordinary least squares models. Our dependent variable is the percentage of all committee chairs in each state legislative chamber who are African American. ${ }^{10}$ Our independent variables are designed to permit us to test the expectations outlined above. They include, first, a measure of partisan con-

${ }^{8}$ Some sense of this can be gleaned from Table 1, which shows that senators, Democrats, and nonfreshman legislators are considerably more likely to be committee chairs than are house members, Republicans, and freshmen.

${ }^{9}$ An example used by Darcy (1996) may help explain this procedure. During the period of his study, the lower house of the Michigan Legislature consisted of 110 members, of whom 20 were Republican freshmen. Of these GOP freshmen, seven (35 percent) served as committee chairs and five ( 25 percent) were women. Hence, the expected number of freshman female Republican committee chairs in the Michigan lower house was $(0.35)(0.25)$ $(20)=1.75$. Similar computations for freshmen Democrats and senior members of both parties yielded a total expectation of 11.84 female committee chairs. When Darcy compared this with the 14 female chairs actually found in the Michigan House of Representatives, he calculated that women held 2.16 more chairs than expected $(14-11.84)$.

${ }^{10} \mathrm{We}$ opt to use percentages due to the large variation among the state legislative chambers in terms of number of committees. We find very similar results when using numbers of black chairs, rather than percentages, as our dependent variable. 
TABLE 1

Number of Members and Number of Committee Chairs for Various State Legislative Groups 1999-2000

\begin{tabular}{lccc}
\hline Group & $\begin{array}{c}\text { Number of } \\
\text { Members }\end{array}$ & $\begin{array}{c}\text { Number of } \\
\text { Committee Chairs }\end{array}$ & $\begin{array}{c}\text { Probability of } \\
\text { Member Being Chair }\end{array}$ \\
\hline $\begin{array}{l}\text { Chamber } \\
\text { Senate }\end{array}$ & 1,968 & 903 & 0.46 \\
$\begin{array}{l}\text { House } \\
\text { Party }\end{array}$ & 5,414 & 1,087 & 0.20 \\
Republican & 3,000 & 596 & 0.20 \\
Democrat & 4,333 & 1,376 & 0.32 \\
Class & & & \\
Freshman & 1,065 & 49 & 0.05 \\
$\begin{array}{l}\text { Other } \\
\text { Race }\end{array}$ & 6,317 & 1,941 & 0.31 \\
African American & & & 0.20 \\
Other & 573 & 116 & 0.28 \\
All & 6,809 & 1,880 & 0.27 \\
\hline
\end{tabular}

trol of the chamber, coded 1 for chambers with a Democratic majority and 0 otherwise. We also include the percentage of African-American members in each chamber, a regional variable (coded 1 for the 11 states of the old Confederacy, 0 otherwise), a measure tapping chair selection techniques (coded 1 if chamber rules permit the presiding officer or some other leader to appoint chairs and 0 otherwise), the relative seniority of the black legislative delegation (coded as the percentage of black freshman in each chamber), and a control variable for chamber level (with state upper houses coded 1 , lower houses 0 ). In our equations for 1999-2000, we also include a measure of whether the state had invoked term limits on its state legislators. Finally, as noted above, we interact each of these last six variables with the partisan variable, which allows us to determine their effect in chambers with Democratic majorities.

\section{Findings}

In our first cut at the data, we examine overall rates of African-American committee chairmanships in our sample of 40 states during 1989, comparing expected rates with those actually observed. ${ }^{11}$ The findings summarized

\footnotetext{
${ }^{11}$ We exclude from our analysis all states and individual chambers that do not possess any black legislators. For both years we exclude both chambers in Alaska, Hawaii, Idaho, Maine, Montana, North Dakota, Utah, and Wyoming. For 1989, we exclude both chambers in New Mexico and South Dakota; we exclude the upper houses in Minnesota, New Hampshire, Vermont, and West Virginia; and the lower house in Iowa. For 1999, we exclude the upper chambers in Arizona, Iowa, Minnesota, New Hampshire, New Mexico, Vermont, and West
} 
in Table 2 reveal a mean difference of approximately -0.20 between the observed number of chairs and the expected number of chairs across all (upper and lower) chambers. The $t$ statistic generated by this comparison $(-1.9)$ is sufficient to meet the threshold of statistical significance $(p \leq 0.06)$, in line with our initial expectation that African Americans are underrepresented as committee chairs.

As the findings summarized in Table 3 attest, the total number of black committee chairs remained almost constant over the decade, increasing by only one (from 115 in 1989 to 116 by 1999). ${ }^{12}$ So, at first glance, the descriptive analyses suggest that the increase in descriptive representation failed to yield an increase in black legislative chairs. Moreover, at the same time, the marked increase in the overall number of African Americans serving in state legislatures drives up our expected observations, resulting in a significantly larger mean difference $(-0.61)$ than observed at the end of the preceding decade. In turn, this generates a much larger-and much more robustly significant $-t$ statistic $(-3.32, p \leq 0.001) .^{13}$

One plausible explanation behind African-American legislators' failure to increase their number of legislative chairmanships is partisanship. ${ }^{14}$ A quick glimpse at recent trends in state legislative politics reveals that the Democratic Party suffered significant setbacks at the state level over the course of the 1990s. At the end of the 1980s, Democrats enjoyed a sizable advantage in the state capitals. In the nation's 98 partisan state legislative chambers (i.e., with the exception of Nebraska's unicameral, nonpartisan legislature), in 1989 Democrats constituted a majority in fully three-quarters (73). A decade later, however, their numbers had slipped dramatically. As of 2000, the GOP controlled a majority (51) of state legislative chambers, leaving Democrats with a majority in only 47 . Although we will return to consider this matter somewhat more below, the combination of nearly monotonic black support for the Democratic Party coupled with the GOP's state-level surge in recent years appears to have had significantly negative consequences for the policy-making roles of black elected officials.

Virginia. Additionally, in the multivariate analyses we follow convention and exclude the nonpartisan, unicameral legislature of Nebraska.

${ }^{12}$ As a close examination of the tables shows, the number of black senate chairs increases slightly from 39 to 42 , but this is offset by a decrease in the number of blacks chairing lower chamber committees (from 76 to 74 ).

${ }^{13} \mathrm{An}$ examination of some of the individual state results reported in Table 3 is instructive. Although some southern states have consistently and notably lower numbers of black committee chairs than expected (e.g., Georgia, Mississippi, and North Carolina), others (such as Louisiana, South Carolina, and Texas) show split results. Alabama has more African-American committee chairs than expected in both its upper and lower houses, and the positive discrepancy between observed and expected chairs in the Alabama Senate is the largest in our data set. Conversely, the largest negative discrepancy is found not in a southern state legislature, but in the lower chamber in Ohio.

${ }^{14}$ Just as clearly, though, partisanship is not the only relevant factor. In Mississippi, the observed number of chairs falls substantially between 1989 and 1999, even though Democrats continued to control both chambers. 
TABLE 2

Expected and Observed African-American Chairs by State and House, 1989

\begin{tabular}{|c|c|c|c|c|c|c|}
\hline \multirow[b]{2}{*}{ State } & \multicolumn{3}{|c|}{$\begin{array}{c}\text { Senate African-American } \\
\text { Chairs }\end{array}$} & \multicolumn{3}{|c|}{ House African-American Chairs } \\
\hline & Observed & Expected & $O-E$ & Observed & Expected & $O-E$ \\
\hline Alabama & 3 & 2.60 & 0.40 & 1 & 5.01 & -4.01 \\
\hline Arizona & 0 & 0.00 & 0.00 & 0 & 0.00 & 0.00 \\
\hline Arkansas & 1 & 0.00 & 1.00 & 0 & 0.69 & -0.69 \\
\hline California & 3 & 2.52 & 0.48 & 2 & 2.44 & -0.44 \\
\hline Colorado & 0 & 0.00 & 0.00 & 0 & 0.00 & 0.00 \\
\hline Connecticut & 2 & 2.45 & -0.45 & 1 & 0.95 & 0.05 \\
\hline Delaware & 1 & 1.67 & -0.67 & 0 & 0.00 & 0.00 \\
\hline Florida & 1 & 2.00 & -1.00 & 2 & 2.95 & -0.95 \\
\hline Georgia & 3 & 3.85 & -0.85 & 3 & 4.44 & -1.44 \\
\hline Illinois & 5 & 4.07 & 0.93 & 3 & 5.00 & -2.00 \\
\hline Indiana & 0 & 0.00 & 0.00 & 3 & 2.27 & 0.73 \\
\hline lowa & 0 & 0.00 & 0.00 & & & \\
\hline Kansas & 0 & 0.00 & 0.00 & 0 & 0.00 & 0.00 \\
\hline Kentucky & 0 & 0.10 & -0.10 & 0 & 0.25 & -0.25 \\
\hline Louisiana & 0 & 1.80 & -1.80 & 3 & 3.11 & -0.11 \\
\hline Maryland & 1 & 2.18 & -1.18 & 3 & 2.88 & 0.12 \\
\hline Massachusetts & 1 & 0.75 & 0.25 & 0 & 0.73 & -0.73 \\
\hline Michigan & 0 & 0.14 & -0.14 & 7 & 6.53 & 0.47 \\
\hline Minnesota & & & 0 & 0.28 & -0.28 & \\
\hline Mississippi & 1 & 1.20 & -0.20 & 8 & 7.72 & 0.28 \\
\hline Missouri & 5 & 3.45 & 1.55 & 6 & 6.84 & -0.84 \\
\hline Nebraska & 0 & 0.00 & 0.00 & & & \\
\hline Nevada & 0 & 0.00 & 0.00 & 1 & 1.00 & 0.00 \\
\hline New Hampshire & & & 0 & 0.00 & 0.00 & \\
\hline New Jersey & 1 & 0.86 & 0.14 & 0 & 0.00 & 0.00 \\
\hline New York & 0 & 0.00 & 0.00 & 4 & 8.00 & -4.00 \\
\hline North Carolina & 3 & 2.82 & 0.18 & 9 & 8.19 & 0.81 \\
\hline Ohio & 0 & 0.00 & 0.00 & 5 & 5.30 & -0.30 \\
\hline Oklahoma & 2 & 0.00 & 2.00 & 2 & 1.68 & 0.32 \\
\hline Oregon & 2 & 1.69 & 0.31 & 1 & 0.80 & 0.20 \\
\hline Pennsylvania & 0 & 0.00 & 0.00 & 3 & 2.37 & 0.63 \\
\hline Rhode Island & 0 & 0.17 & -0.17 & 0 & 0.36 & -0.36 \\
\hline South Carolina & 0 & 1.61 & -1.61 & 2 & 1.76 & 0.24 \\
\hline Tennessee & 3 & 1.20 & 1.80 & 1 & 1.93 & -0.93 \\
\hline Texas & 0 & 0.60 & -0.60 & 3 & 2.84 & 0.16 \\
\hline Vermont & & & 0 & 0.23 & -0.23 & \\
\hline Virginia & 0 & 0.42 & -0.42 & 0 & 2.07 & -2.07 \\
\hline Washington & 0 & 0.00 & 0.00 & 0 & 0.39 & -0.39 \\
\hline West Virginia & & & 1 & 0.36 & 0.64 & \\
\hline Wisconsin & 1 & 0.94 & 0.06 & 2 & 2.33 & -0.33 \\
\hline Total & 39 & 39.09 & -0.09 & 76 & 91.70 & -15.70 \\
\hline
\end{tabular}

Mean difference $=-0.20$.

$t$ statistic $=-1.90$.

$P$ value $\leq 0.06$ (two-tailed test). 
TABLE 3

Expected and Observed African-American Chairs by State and House, 1999

\begin{tabular}{|c|c|c|c|c|c|c|}
\hline \multirow[b]{2}{*}{ State } & \multicolumn{3}{|c|}{$\begin{array}{c}\text { Senate African-American } \\
\text { Chairs }\end{array}$} & \multicolumn{3}{|c|}{ House African-American Chairs } \\
\hline & Observed & Expected & $O-E$ & Observed & Expected & $O-E$ \\
\hline Alabama & 8 & 6.32 & 1.68 & 9 & 8.11 & 0.89 \\
\hline Arizona & & & 0 & 0.00 & 0.00 & \\
\hline Arkansas & 1 & 1.62 & -0.62 & 1 & 0.83 & 0.17 \\
\hline California & 0 & 1.33 & -1.33 & 4 & 2.58 & 1.42 \\
\hline Colorado & 0 & 0.00 & 0.00 & 0 & 0.00 & 0.00 \\
\hline Connecticut & 3 & 3.47 & 0.53 & 1 & 2.63 & -1.63 \\
\hline Delaware & 2 & 1.83 & 0.17 & 0 & 0.00 & 0.00 \\
\hline Florida & 0 & 0.45 & -0.45 & 0 & 0.36 & -0.36 \\
\hline Georgia & 5 & 7.43 & -2.43 & 5 & 10.74 & -5.74 \\
\hline Illinois & 0 & 0.00 & 0.00 & 10 & 10.62 & -0.62 \\
\hline Indiana & 0 & 0.00 & 0.00 & 3 & 2.68 & 0.32 \\
\hline lowa & & & 0 & 0.00 & 0.00 & \\
\hline Kansas & 0 & 0.00 & 0.00 & 0 & 0.00 & 0.00 \\
\hline Kentucky & 0 & 0.00 & 0.00 & 0 & 1.24 & -1.24 \\
\hline Louisiana & 5 & 4.40 & 0.60 & 1 & 2.67 & -1.67 \\
\hline Maryland & 3 & 3.10 & -0.10 & 3 & 2.72 & 0.28 \\
\hline Massachusetts & 1 & 0.93 & 0.07 & 1 & 1.10 & -0.10 \\
\hline Michigan & 0 & 0.00 & 0.00 & 0 & 0.00 & 0.00 \\
\hline Minnesota & & & 0 & 0.00 & 0.00 & \\
\hline Mississippi & 4 & 7.31 & -3.31 & 3 & 8.50 & -5.50 \\
\hline Missouri & 2 & 3.35 & -1.35 & 3 & 6.72 & -3.72 \\
\hline Nebraska & 0 & 0.00 & 0.00 & & & \\
\hline Nevada & 0 & 0.91 & -0.91 & 2 & 0.92 & 1.08 \\
\hline New Hampshire & & & 0 & 0.00 & 0.00 & \\
\hline New Jersey & 0 & 0.00 & 0.00 & 0 & 0.33 & -0.33 \\
\hline New Mexico & & & 1 & 0.00 & 1.00 & \\
\hline New York & 0 & 0.32 & -0.32 & 6 & 9.71 & -3.71 \\
\hline North Carolina & 3 & 4.29 & -1.29 & 10 & 12.82 & -2.82 \\
\hline Ohio & 0 & 0.00 & 0.00 & 0 & 8.56 & -8.56 \\
\hline Oklahoma & 2 & 0.97 & 1.03 & 2 & 1.38 & 0.62 \\
\hline Oregon & 0 & 0.00 & 0.00 & 0 & 0.00 & 0.00 \\
\hline Pennsylvania & 0 & 0.00 & 0.00 & 0 & 0.00 & 0.00 \\
\hline Rhode Island & 0 & 0.17 & -0.17 & 0 & 0.00 & 0.00 \\
\hline South Carolina & 0 & 2.92 & -2.92 & 1 & 0.46 & 0.54 \\
\hline South Dakota & 0 & 0.00 & 0.00 & 0 & 0.00 & 0.00 \\
\hline Tennessee & 1 & 1.41 & -0.41 & 2 & 2.85 & -0.85 \\
\hline Texas & 1 & 0.50 & 0.50 & 3 & 4.40 & -1.40 \\
\hline Vermont & & & 0 & 0.00 & 0.00 & \\
\hline Virginia & 0 & 0.00 & 0.00 & 3 & 4.00 & -1.00 \\
\hline Washington & 0 & 0.61 & -0.61 & 0 & 0.00 & 0.00 \\
\hline West Virginia & & & R & 0.52 & -0.52 & \\
\hline Wisconsin & 1 & 2.00 & -1.00 & 0 & 0.00 & 0.00 \\
\hline Total & 42 & 55.64 & -13.64 & 74 & 107.45 & -33.45 \\
\hline
\end{tabular}

Mean difference $=-0.62$.

$t$ statistic $=-3.32$.

$P$ value $\leq 0.001$ 
Before turning to the multivariate models, we first focus on disaggregating the data, in order to examine the relative prevalence of African-American chairs across committee types. Specifically, we are interested in testing our expectations that African-American chairs will be underrepresented on important control committees, and overrepresented on those dealing with issues of historical importance to minority communities (e.g., education, health, and social services). To assess the accuracy of these expectations, we again employ techniques used by Darcy (1996). First, we divide the committees in the state legislatures under consideration here into 19, overlapping jurisdictional categories. ${ }^{15}$ Second, recalling from Table 1 that African Americans chair approximately 6 percent of all state legislative committees $(116 / 1990)$, we can calculate expected numbers of black chairs by multiplying the overall percent of black chairs $(p)$ by the number of committees in each jurisdictional domain $(n)$. For example, in the area of social services there are 162 committees in our analysis, yielding an expected number of 9.72 African-American chairs: $(162)(0.06)=9.72$. After computing a standard deviation, ${ }^{16}$ we can then compare the expected prevalence of black chairs in each jurisdictional domain versus our actual observations.

This analysis, using data from 1999-2000, is summarized in Table $4 .{ }^{17} \mathrm{At}$ best, it provides only mixed support for our hypotheses. First, in terms of important control committees that structure their parent chambers' fiscal and legislative decisions, we find-contrary to our expectations-that African Americans are not significantly underrepresented as chairs on fiscal and rules committees. Although both categories generate negative $Z$ coefficients, indicating that there are fewer minority chairs than we would expect, the differences are neither substantively large nor statistically significant. ${ }^{18}$

Our expectations fare somewhat better when it comes to committees dealing with health and social services—areas in which African Americans have a great interest and in which minority representatives introduce a disproportionate number of bills. There are more African-American chairs

\footnotetext{
${ }^{15}$ The jurisdictional areas are derived from categories developed by the Council of State Governments and used by Darcy (1996). In alphabetical order, these are: agriculture, banking/financial institutions, business and commerce, communication, education, elections, energy, environment/natural resources, ethics, fiscal, government operations, health, insurance, judiciary, local affairs, public employees, rules, social services, and transportation. Since committees can fit into more than one category, the numbers used here do not match those in Table 1.

${ }^{16}$ Again, we follow Darcy (1996) by calculating the standard deviation as $[n p(1-p)]^{1 / 2}$.

${ }^{17}$ Results from the earlier time period (1989-1990) are excluded here for purposes of brevity, but are available from the authors. With some minor variations, they show much the same patterns visible in the 1999-2000 data.

${ }^{18}$ It may also be worth noting that African Americans are not significantly underrepresented as chairs of business and commerce committees; in fact they are slightly overrepresented, a fact that may be attributable to recent increases in African-American legislators who come from business backgrounds (see Holmes, 2000; Orey 2000; but see Clemons and Jones, 2000). On the other hand, African Americans are significantly underrepresented on committees that handle banking and financial institution matters, and even more so on committees with jurisdiction over natural resources, insurance, and agriculture.
} 
TABLE 4

Expected and Observed African-American Chairs by Committee Function: 1999-2000

\begin{tabular}{lrccr}
\hline Committee Function & $\begin{array}{c}\text { Number of } \\
\text { Committees }\end{array}$ & $\begin{array}{c}\text { Observed } \\
\text { Black Chairs }\end{array}$ & $\begin{array}{c}\text { Expected } \\
\text { Black Chairs }\end{array}$ & \multicolumn{1}{c}{$Z$} \\
\hline Agriculture & 114 & 1 & 6.84 & -2.30 \\
Banking/financial institution & 113 & 2 & 6.78 & -1.90 \\
Business and commerce & 163 & 11 & 9.78 & 0.40 \\
Communications & 115 & 0 & 6.9 & -2.71 \\
Education & 136 & 7 & 8.16 & -0.42 \\
Elections & 107 & 3 & 6.42 & -1.39 \\
Energy & 108 & 0 & 6.48 & -2.62 \\
Environmental/natural & 161 & 3 & 9.66 & -2.21 \\
$\quad$ resources & & & & \\
Ethics & 97 & 1 & 5.82 & -2.06 \\
Fiscal & 183 & 10 & 10.98 & -0.31 \\
Government operations & 143 & 17 & 8.58 & 2.96 \\
Health & 126 & 11 & 7.56 & 1.27 \\
Insurance & 99 & 3 & 5.94 & -1.32 \\
Judiciary/corrections & 137 & 12 & 8.22 & 1.36 \\
Local affairs & 142 & 16 & 8.52 & 2.59 \\
Public employees & 138 & 2 & 8.28 & -2.25 \\
Rules & 103 & 5 & 6.18 & -0.49 \\
Social services & 162 & 19 & 9.72 & 3.07 \\
Transportation & 114 & 7 & 6.84 & 0.06 \\
Totals & 2,461 & 130 & & \\
\hline
\end{tabular}

of committees responsible for social services (19) than in any category; this number is far larger than we would expect based on chance (9.72) and it generates a robustly significant $Z$ score of 3.07 . There are also somewhat more black chairs of health-oriented committees than we would expect, although the difference is not statistically significant. Contrary to expectations, there are slightly fewer African Americans chairing committees in the educational area, although, again, the difference does not approach statistical significance. ${ }^{19}$

${ }^{19}$ Although not directly related to our initial expectations, several other results from Table 4 deserve at least passing comment. First, although not statistically significant, African Americans do appear to be somewhat overrepresented as chairs of judiciary/corrections committees. Since the high incarceration rates of African Americans and their concomitant cynicism toward the U.S. judicial system have been well documented perhaps this represents a sanguine development in terms of shoring up diffuse support for the judiciary among minority communities. Second, given the fact that African Americans are proportionately more dependent on government employment than are whites, it is perhaps surprising that African-American legislators are significantly underrepresented as chairs on committees that deal with matters relating to public employees. Indeed, as the estimates in Table 4 indicate, they hold less than one-quarter of the chairs predicted in this area. Third, the relatively large number of black chairs of local affairs committees defies immediate explanation. Since this 
Turning from a description of the pattern of African-American committee chairs in the state legislatures to attempting to account for some of the factors influencing that pattern, we developed multivariate regression models, results from which we summarize in Table 5. As outlined above, our dependent variable is the percentage of black committee chairs in each chamber in our analysis and our independent variables include a number of partisan, political, demographic, geographic, and institutional features. We run separate estimations for 1989-1990 and 1999-2000. ${ }^{20}$

Overall and viewed together, these results augment the portrayal presented in Tables 2 and 3. In 1989, during a period of Democratic dominance in the state legislatures, the principal factor affecting the presence of black committee chairs was the percentage of black legislators in the chamber. To the extent that other factors affected the selection of black committee chairs, their substantive impact was only marginal even if they were statistically significant. For example, after controlling for other relevant factors, southern legislatures had fewer black chairs than might otherwise be expected, but the coefficient is small and its significance modest $(p \leq 0.07)$. Similarly, while it is interesting that the interactive variable for black caucus size and Democratic control generates a negatively signed coefficient, the size of its impact is substantively small.

By 1999, after a decade of racial redistricting successfully designed to bring scores of new African Americans into the state legislatures, but that also witnessed marked GOP electoral success at the state legislative level, the dynamics of black committee chair selection had clearly changed. As the results in the right-hand column of Table 5 show, at the turn of the millennium the interaction of black legislative presence and Democratic partisan control had become the predominant factor influencing the presence of African-American committee chairs. Over the course of the decade, this term has flipped signs, now showing a strong positive correlation between the interaction and the selection of black chairschambers with both large numbers of black members and Democratic

category seems to include something of a hodge-podge of committees with varied and what appear to be rather constrained jurisdictions, it is possible that these positions are essentially "tokens" and indicate only limited legislative power. In this regard, it is perhaps worth noting that 14 of these 16 committees are found in southern state legislative chambers.

${ }^{20}$ Since our data are cross-sectional and involve results from both upper and lower chambers (which might threaten the independence of observations), we err on the side of caution, calculating our results with robust standard errors. We have also opted to report here the equations that include data from all the states included in our sample, not just those chambers controlled by Democrats. We do so to maximize our statistical leverage and to avoid charges of selecting on the dependent variable. Results from analysis of just those chambers with Democratic majorities yield substantive results that are virtually identical to those reported in Table 5. 
TABLE 5

OLS Models (with Robust Standard Errors) of Factors Influencing Percentages of Black State Legislative Committee Chairs

\begin{tabular}{lcc}
\hline Variable & 1989 & 1999 \\
\hline Percent black & $0.025 * * *$ & 0.056 \\
& $(0.006)$ & $(0.082)$ \\
Democratic control & 0.040 & -0.018 \\
& $(0.039)$ & $(0.027)$ \\
Southern states & $-0.030 *$ & $0.035 * *$ \\
& $(0.017)$ & $(0.015)$ \\
Percent black freshmen & $-0.020 * * *$ & 0.247 \\
& $(0.008)$ & $(0.218)$ \\
Leadership appointment & -0.047 & -0.003 \\
& $(0.036)$ & $(0.010)$ \\
Chamber & -0.022 & -0.008 \\
& $(0.025)$ & $(0.007)$ \\
Term limits & & $-0.010 *$ \\
Percent black $\times$ Democratic control & & $(0.006)$ \\
Southern states $\times$ Democratic control & $-0.013 * *$ & $0.711 * *$ \\
Percent black freshmen $\times$ Democratic control & $(0.006)$ & $(0.317)$ \\
Leadership appointments $\times$ Democratic control & & $0.060 *$ \\
Chamber $\times$ Democratic control & 0.012 & $(0.034)$ \\
Term limits $\times$ Democratic control & $(0.009)$ & 0.685 \\
$R^{2}$ & 0.052 & $(0.427)$ \\
$N$ & $(0.039)$ & 0.033 \\
\hline
\end{tabular}

Note: $* p<0.10 ; * * p<0.05 ; * * * p<0.01$.

majorities saw larger than expected percentages of black chairs. ${ }^{21}$ Here, we find the exact opposite picture when compared to 1989. That is, when examining Democratic-controlled chambers, the percent black in a state legislature increases the percentage of black chairs.

Interestingly, while the coefficient for the southern regional dummy variable has become positive in the 1999 model, the interactive regional Democratic control variable is negatively signed and (at least marginally) significant $(p \leq 0.085)$, indicating that in those states that have experienced

\footnotetext{
${ }^{21}$ In part, this change results because the correlation between the percentage of black representatives in a legislature and Democratic control of the legislature had fallen by the late 1990 s, from 0.26 to 0.20 . As a result, it was less likely that chambers with substantial AfricanAmerican caucuses had Democratic majorities, highlighting the importance of both conditions.
} 
the most extensive racial redistricting and where (white) Democrats control the legislative chamber, we see at least somewhat fewer black chairs than in otherwise similarly situated legislative chambers As previous case studies have suggested (Orey 2000), there is some evidence of a backlash among southern white Democratic legislators, although the size of the effect may be smaller than some had expected. ${ }^{22}$

\section{Discussion and Conclusions}

Over the past few decades, African Americans have made enormous gains in the number of state legislative seats they hold. Although these gains have been well documented, researchers have been slower to investigate the impacts of such changes on the quality of black representation. In this article, we examine one aspect of the growing presence of minority legislators, the extent to which they chair legislative committees. In doing so, we present the first comprehensive assessment of this important aspect of state legislative politics, illuminating the extent to which black legislators have been able to translate electoral victories into real legislative power and the conditions under which this is likely to occur.

The data paint a somewhat mixed portrait of the status of black legislative clout at the beginning of the new millennium. On the one hand, there is much positive news. Contrary to our expectations, compared to their overall numbers in state legislatures, African Americans are not significantly underrepresented as chairs of the important legislative committees that shape the states' fiscal policies and legislative processes, a clear indication that black legislators are involved in key taxing, spending, and procedural decisions. Equally important, African Americans are considerably overrepresented as chairs of committees dealing with issues of health care and social services, traditionally areas of strong interest to the black community. This indicates that in policy areas of greatest interest to their constituents, black state legislators have been able to move beyond the symbolism of merely holding elective office into real positions of power where they can provide significant substantive representation. Moreover, our data indicate that black legislators have been able to continue exercising this substantive power even after a decade in which the GOP made enormous gains at the state level, significantly reducing Democratic power in the nation's state capitols. Especially when viewed in historical perspective regarding where African-American representation was a mere two generations ago, the size and resilience of these gains are notable.

But there is disturbing news as well. Over the course of the 1990s, gains in elected black state legislators were not matched by similar gains in committee chairs. Indeed, there was a net gain of only one during the

\footnotetext{
${ }^{22}$ The term-limit variable also behaves as expected, generating a negative and modestly significant coefficient, suggesting that term limits have something of a pernicious effect on minority representation.
} 
decade. In large measure, this disjuncture has partisan roots; the near total absence of black Republican state legislators means that legislative chambers with GOP majorities have very few African-American committee chairs. This partisan shift in legislative control greatly attenuated the impact of the scores of new African-American legislators elected in the wake of the 1982 amendments to the Voting Rights Act, who otherwise would have chaired many more state legislative committees. Is this mere coincidence? Or are the two developments related? Intense academic and public debate has surrounded this and similar questions, and our data do not allow us to make definitive determinations here. It is worth noting, however, that there is a significant correlation between the increase in the percentage of black legislators in a state legislative chamber between 1989 and 1999, and the likelihood that the chamber would switch from a Democratic to a Republican majority $(r=0.30 ; p \leq 0.01)$. Although we acknowledge that numerous other factors besides racial redistricting are likely to be at work in driving this partisan change (see Lublin and Voss, 2000 for a lengthy analysis of this topic; at the congressional level, see also Engstrom, 2006), the correlation does suggest something of the stark conundrum facing the nation's AfricanAmerican population and politicians: real legislative power requires the election of large contingents of African-American state legislators, but conditions conducive to such electoral results may endanger the Democratic majorities that are also necessary for significant black policy impact.

Overall, our results reinforce the point that in the contemporary state legislative political environment, black legislators have become key caucuses within the Democratic Party; wherever the party holds a majority and its black members hold sufficient seats, a sizable percentage of committee chairs is virtually assured, regardless of other institutional or political factors. In such chambers, descriptive representation clearly has translated itself into substantive representation, assuming that African-American committee chairs engage in policy outcomes of interest to African Americans. Conversely, however, the other side of the proverbial coin is that absent the confluence of relatively large numbers and Democratic partisan control, the prospects for African-American committee chairs are bleak indeed. The near total absence of black members in the Republican legislative caucuses of necessity relegates black legislators to secondary or tertiary leadership roles in chambers controlled by the GOP. In such chambers, African-American legislators retain important functions, but as Grofman (2006:64) has recently noted, these will be less substantive in nature and more in terms of "sounding the alarm and providing vocal and potentially embarrassing protests against attempts to harm minority interests."

\section{REFERENCES}

APSA. 1993. "Where Minorities Are the Majority." APSA Legislative Studies Section Newsletter 17(1):23. 
Brace, Kimball, Bernard Grofman, and Lisa Handley. 1987. "Does Redistricting Aimed to Help Blacks Necessarily Help Republicans?” Journal of Politics 49:169-85.

Bratton, Kathleen A., and Kerry L. Haynie. 1999. "Agenda-Setting and Legislative Success in State Legislatures: The Effects of Gender and Race." Journal of Politics 61:658-79.

Bullock, Charles S. 1995. "Affirmative Action Districts: In Whose Faces Will They Blow Up?" Campaigns and Elections April:22.

Butler, David, and Bruce E. Cain. 1992. Congressional Redistricting: Comparative and Theoretical Perspectives. New York: MacMillan.

Cameron, Charles, David Epstein, and Sharyn O’Halloran. 1996. "Do Majority-Minority Districts Maximize Black Representation in Congress?" American Political Science Review 90:794-812.

Carey, John M., Richard G. Niemi, and Lynda W. Powell. 2000. Term Limits in State Legislatures. Ann Arbor, MI: University of Michigan Press.

Carey, John M., Richard Niemi, Lynda W. Powell, and Gary R. Moncrief. 2006. "The Effects of Term Limits on State Legislatures: A New Survey of the 50 States." Legislative Studies Quarterly 31:105-34.

Clemons, Michael, and Charles E. Jones. 2000. "African American Legislative Politics in Virginia." Journal of Black Studies 30:744-67.

Darcy, Robert. 1996. "Women in the State Legislative Power Structure: Committee Chairs." Social Science Quarterly 77:888-98.

Darcy, Robert, Susan Welch, and Janet Clark. 1994. Women, Elections, and Representation, 2nd ed. Lincoln, NE: University of Nebraska Press.

Davidson, Chandler, and Bernard Grofman, eds. 1994. Quiet Revolution in the South. Princeton, NJ: Princeton University Press.

Davidson, Roger H., and Walter J. Oleszek. 2006. Congress and Its Members, 10th ed. Washington, DC: CQ Press.

Engstrom, Richard L. 2006. "Race and Southern Politics: The Special Case of Congressional Districting." In Robert Steed and Laurence Moreland, eds., Writing Southern Politics: Current Interpretations and Future Directions. Lexington, KY: University Press of Kentucky.

Fenno, Richard F., Jr. 1973. Congressmen in Committees. Boston, MA: Little, Brown.

Gerber, Alan. 1996. "African Americans' Congressional Careers and the Democratic House Delegation." Journal of Politics 58:831-45.

Grofman, Bernard. 2006. "Operationalizing the Section 5 Retrogression Standard of the Voting Rights Act in the Light of Georgia v. Ashcroft: Social Science Perspectives on Minority Influence, Opportunity and Control.” Manuscript. University of California, Irvine.

Grose, Christian R. 2005. "Disentangling Constituency and Legislators Effects in Legislative Representation: Black Legislators or Black Districts?” Social Science Quarterly 86:427-43.

Guinier, Lani. 1994. "What Color is Your Gerrymander?" Washington Post March 27:C3.

Hall, Richard L. 1996. Participation in Congress. New Haven, CT: Yale University Press.

Haynie, Kerry L. 2001. African American Legislators in the American States. New York: Columbia University Press.

2002. "The Color of Their Skin or the Content of Their Behavior? Race and Perceptions of African American Legislators." Legislative Studies Quarterly 27:295-314. 
Hill, Kevin A. 1995. "Does the Creation of Majority Black Districts Aid Republicans? An Analysis of the 1992 Congressional Elections in Eight Southern States." Journal of Politics 57:384-401.

Holmes, Robert. 2000. "The Georgia Legislative Black Caucus: An Analysis of a Racial Legislative Subgroup.” Journal of Black Studies 30:768-90.

Jewell, Malcolm E., and Samuel C. Patterson. 1986. The Legislative Process in the United States. New York: Random House.

Joint Center for Political and Economic Studies. 1993. Black Elected Officials: A National Roster. Washington, DC: Joint Center for Political and Economic Studies Press.

Keefe, William J., and Morris S. Ogul. 2001. The American Legislative Process: Congress and the States, 10th ed. Upper Saddle River, NJ: Prentice-Hall.

Lacy, A. B. 1967. Power in American State Legislatures. New Orleans, LA: Tulane University Press.

Legette, William M. 2000. "The South Carolina Legislative Black Caucus, 1970 to 1988." Journal of Black Studies 30:791-814.

Lublin, David I. 1997. The Paradox of Representation. Princeton, NJ: Princeton University Press.

Lublin, David I., and D. Stephen Voss. 2000. "Racial Redistricting and Realignment in Southern State Legislatures." American Journal of Political Science 44:782-810.

Mayhew, David. 1974. Congress: The Electoral Connection. New Haven, CT: Yale University Press.

Myrdal, Gunnar. 1944. American Dilemma. New York: Harper and Bros.

National Conference of State Legislatures. 2005. Term Limits: Legislative Term Limits Overview. Available at $\langle$ http://www.ncsl.org/programs/legman/ABOUT/termlimit.htm $\rangle$.

National Public Radio. 1993. "Black Caucus Unable to Get Bills Passed." Morning Edition April 30.

Orey, Byron D’Andra. 2000. “Black Legislative Politics.” Journal of Black Studies 30:791814 .

Orey, Byron D'Andra, and Wendy G. Smooth, with Kimberly Adams and Kisha HarrisClark. Forthcoming. "Race and Gender Matter: Building Better Models of Legislative Policy Making in State Legislatures." Journal of Women, Politics and Policy.

Overby, L. Marvin, and Kenneth M. Cosgrove. 1996. "Unintended Consequences?: Racial Redistricting and the Representation of Minority Interests." Journal of Politics 58:540-50.

Pitkin, Hanna. 1967. The Concept of Representation. Berkeley, CA: University of California Press.

Shotts, Kenneth W. 2001. "The Effect of Majority-Minority Mandates on Partisan Gerrymandering." American Journal of Political Science 45:120-35.

Smith, Steven S., and Christopher J. Deering. 1990. Committees in Congress, 2nd ed. Washington, DC: CQ Press.

Swain, Carol. 1993. Black Faces, Black Interests: The Representation of African Americans in Congress. Cambridge: Harvard. 